\title{
Bacteroides zoogleoformans (Weinberg, Nativelle, and Prévot 1937) corrig., comb. nov.: Emended Description
}

\author{
ELIZABETH P. CATO, R. W. KELLEY, W. E. C. MOORE, AND LILLIAN V. HOLDEMAN \\ Department of Anaerobic Microbiology, College of Agriculture and Life Sciences, Virginia Polytechnic \\ Institute and State University, Blacksburg, Virginia 24061
}

Received/Accepted

\begin{abstract}
The type strain of Capsularis zoogleiformans (sic) (Weinberg et al. 1937) Prévot 1938, strain ATCC 33285 (= VPI D28K-1), has characteristics that are consistent with those of the genus Bacteroides as it is presently defined. Therefore, we propose that this species be transferred to the genus Bacteroides as Bacteroides zoogleoformans (Weinberg et al.) comb. nov. An emended description of the species is provided.
\end{abstract}

In 1938, Prévot (9) proposed the new genus Capsularis to accommodate the anaerobic, gram-negative, nonmotile, nonsporeforming, rod-shaped bacteria that form capsules. Hauduroy et al. (2) designated as the type species of this genus the first species listed by Prévot (9), Capsularis zoogleiformans (sic), previously "Bacterium zoogleiformans" (sic) Weinberg et al. (12) (not on the Approved Lists of Bacterial Names [11]). No strains of this species had been available for study since 1922 (10), but because of the excellence of the original description, the species could be recognized easily.

During an investigation of the flora of gingival crevices in human periodontal disease, we isolated several strains with the distinctive characteristics noted by Weinberg et al. (12) in their description of "Bacterium zoogleiformans." Further study of these organisms showed that they are clearly strains of the genus Bacteroides as presently defined (8); i.e., they are obligately anaerobic, gram-negative, nonsporeforming rods with metabolic products that include acetic, propionic, isovaleric, and succinic acids. One of these strains, strain D28K-1, was designated on the Approved Lists (11) as the type strain of Capsularis zoogleiformans and has been deposited in the American Type Culture Collection under the number ATCC 33285.

The correct form of the specific epithet for this species is zoogleoformans (T. M. MacAdoo, personal communication). This word is derived from the Greek adjective zoos, alive or living, and the Greek masculine noun gloios, gum or glue: living glue, very descriptive of the type of growth formed in broth cultures. We propose that $C$. zoogleiformans be reclassified as Bacteroides zoogleoformans (Weinberg et al.) comb. nov. and that ATCC 33285 be retained as the type strain of the species.

\section{MATERIALS AND METHODS}

Bacterial strains. Strain VPI D28K-1 $(=$ ATCC 33285) and eight similar strains were isolated in our laboratory from subgingival crevices of patients with severe periodontitis. The type strains of other species with which these strains were compared are listed in Table 1.

Media and methods. The reactions and characteristics of strain ATCC 33285 were determined by using prereduced, anaerobically sterilized media and anaerobic methods which have been described previously (4). Unless otherwise specified, all media contained vitamin $K_{1}$ and hemin. Tubes of media were inoculated under a stream of oxygen-free $\mathrm{CO}_{2}$. A $10 \% \mathrm{CO}_{2-}$ $90 \% \mathrm{H}_{2}$ atmosphere was used for anaerobic incubation of plates.

The patterns of the soluble cellular proteins of the strains examined were determined by the polyacrylamide slab gel electrophoresis procedure described by Moore et al. (7). The broken cell preparations were heated at $55^{\circ} \mathrm{C}$ for $5 \mathrm{~min}$ before centrifugation.

Susceptibilities to penicillin $\mathrm{G}(2 \mathrm{U} / \mathrm{ml})$, clindamycin $(1.6 \mu \mathrm{g} / \mathrm{ml})$, tetracycline $(6 \mu \mathrm{g} / \mathrm{ml})$, chloramphenicol $(12 \mu \mathrm{g} / \mathrm{ml})$, and erythromycin $(3 \mu \mathrm{g} / \mathrm{ml})$ were determined by the broth disk method of Wilkins and Thiel (13).

Other biochemical tests and gas-liquid chromatographic determinations of acid end products of fermentation and of hydrogen gas were performed as previously described (4). J. L. Johnson determined the guanine-plus-cytosine content of a preparation of deoxyribonucleic acid by the thermal melting point method $(3,6)$.

\section{RESULTS AND DISCUSSION}

The growth characteristics of strain ATCC 33285 were distinctive and exactly as previously described $(10,12)$. A viscous, glutinous mass which was very difficult to remove with a capillary pipette formed in broth cultures, especially cultures containing fermentable carbohydrate (Fig. 1). This organism was strictly anaerobic and nonmotile and grew well at 30 and $37^{\circ} \mathrm{C}$, 
TABLE 1. Bacterial strains examined

\begin{tabular}{|c|c|}
\hline VPI no. ${ }^{a}$ & Source \\
\hline $28 \mathrm{~K}-1$ & $\begin{array}{c}\text { ATCC } 33285 \text { (type strain of } \\
\text { Bacteroides zoogleoformans) }\end{array}$ \\
\hline 13166 & $\begin{array}{l}\text { ATCC } 33269 \text { (type strain of } B . \\
\text { oralis) }\end{array}$ \\
\hline 0061 & $\begin{array}{r}\text { ATCC } 8492 \text { (type strain of } B . \\
\text { uniformis) }\end{array}$ \\
\hline $0051 \mathrm{~B}$ & $\begin{array}{l}\text { M. P. Bryant strain 23. Parent strain } \\
\text { of ATCC } 19189 \text { (type strain of } \\
\text { B. ruminicola subsp. ruminicola) }\end{array}$ \\
\hline 0050 & $\begin{array}{l}\text { M. P. Bryant strain GA33. Parent } \\
\text { strain of ATCC } 19188 \text { (type } \\
\text { strain of B. ruminicola subsp. } \\
\text { brevis) }\end{array}$ \\
\hline D1 A-1A & $\begin{array}{l}\text { ATCC } 33573 \text { (type strain of } B . \\
\text { oris) }\end{array}$ \\
\hline D3A-6A & $\begin{array}{l}\text { ATCC } 33574 \text { (type strain of } B . \\
\text { buccae) }\end{array}$ \\
\hline
\end{tabular}

\footnotetext{
${ }^{a}$ VPI, Virginia Polytechnic Institute and State University.
}

slightly at $25^{\circ} \mathrm{C}$, and not at all at $45^{\circ} \mathrm{C}$. Hemin was required for growth since this strain did not survive a third transfer into hemin-free medium. There was no growth in peptone-yeast extractglucose medium supplemented with $20 \%$ bile. No gas was detected in peptone-yeast extractglucose agar deep cultures, and cultures were odorless.

After $24 \mathrm{~h}$ of incubation at $37^{\circ} \mathrm{C}$ in peptoneyeast extract-glucose broth, the cells of strain ATCC 33285 were gram-negative, nonsporeforming rods with rounded ends (Fig. 2). These cells stained unevenly, and they were straight or slightly curved and 0.4 to 0.8 by 0.8 to $8.0 \mu \mathrm{m}$;

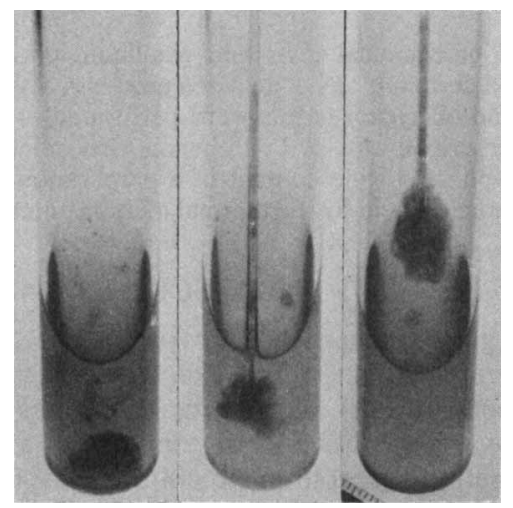

FIG. 1. Zoogleal mass formed in chopped meat broth culture by $B$. zoogleoformans ATCC 33285. usually they occurred singly, but occasionally they occurred in pairs.

Surface colonies on 48-h-old blood agar plates incubated anaerobically were nonhemolytic, 0.5 to $2.0 \mathrm{~mm}$ in diameter, circular, entire, pulvinate, opaque, buff colored, shiny, smooth, and butyrous. No internal structure was visible.

The amounts of fermentation acids which were detected in a 4-day-old peptone-yeast extract-glucose broth culture were as follows (in milliequivalents per $100 \mathrm{ml}$ ): succinic acid, 4.6; acetic acid, 1.8; propionic acid, 0.3 ; and isovaleric acid, 0.2. Hydrogen production was dependent on culture conditions; large amounts were produced when strain ATCC 33285 was inoculated under a gas mixture containing $90 \%$ nitrogen and $10 \% \mathrm{CO}_{2}$ into media supplemented with rabbit serum (final concentration, 9\%), and little or no hydrogen was detected when the strain was inoculated under $100 \% \mathrm{CO}_{2}$ into media without serum.

As stated in the original description (12), glucose, maltose, fructose, sucrose, and lactose were fermented strongly (to a $\mathrm{pH}$ of 5.5 or lower, compared with a final $\mathrm{pH}$ of 6.1 in basal broth medium), galactose was fermented weakly (pH 5.6) and mannitol was not fermented. In addition, we found that arabinose, cellobiose, dextrin, glycogen, inulin, mannose, pectin, raffinose, salicin, starch, and xylose were fermented strongly and that melibiose was fermented weakly. Adonitol, amygdalin, dulcitol, erythritol, esculin, glycerol, inositol, melezitose, rhamnose, ribose, sorbitol, sorbose, trehalose, gum arabic, larch arabinogalactan, and xylan were not fermented, although growth was good with all of these substrates.

Strain ATCC 33285 produced ammonia in peptone-yeast extract broth cultures and $\mathrm{H}_{2} \mathrm{~S}$ in SIM medium (BBL Microbiology Systems, Cockeysville, Md.). Urease, catalase, lecithinase, lipase, and deoxyribonuclease were not detected. This strain hydrolyzed esculin and starch. A solid acid curd formed in milk. After 3 weeks of incubation, a chilled gelatin culture liquefied after $15 \mathrm{~min}$ at room temperature, whereas an uninoculated control was still solid after 60 min. Neither milk nor meat was digest-

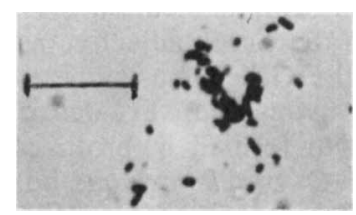

FIG. 2. B. zoogleoformans, ATCC 33285 ; crystal violet simple stain of a 48-h-old culture in peptone-yeast extract broth, $\operatorname{Bar}=10 \mu$. 


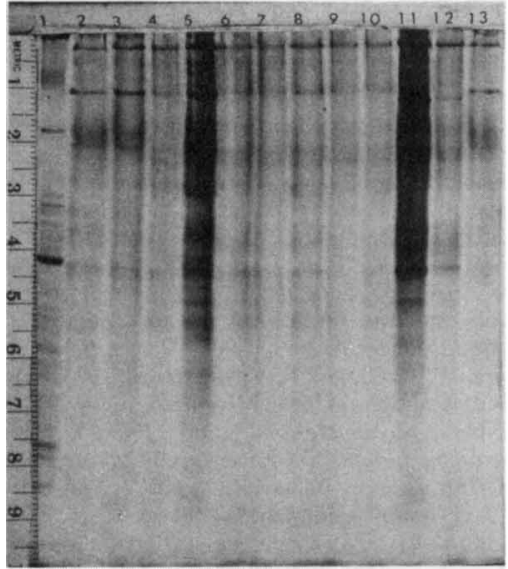

FIG. 3. Electrophoretic patterns of strains of Bacteroides zoogleoformans. Lane 1, Streptococcus faecalis reference strain U4-20; lanes 2 and 13, D28K-1 (parent strain of ATCC 33285) from patient 1 ; lane 3, ATCC 33285 (type strain); lanes 4-10, six isolates from subgingival crevice in patient 2 (D13D); lane 11 , D48C-7 (patient 3); lane 12, D49D-21 (patient 4).

ed. Indole was not produced. Nitrate was not reduced.

Pyruvate was converted to acetate, but propionate was not formed from either lactate or threonine. Strain ATCC 33285 was susceptible to the concentrations of chloramphenicol, clindamycin, erythromycin, penicillin $\mathrm{G}$, and tetracycline tested.

The guanine-plus-cytosine content of strain ATCC 33285 deoxyribonucleic acid was 47 mol\%.

Characteristics of other strains of $B$. zoogleoformans. Eight other strains with the distinctive type of growth shown by strain ATCC 33285 were isolated from the subgingival crevices of three other patients with periodontitis. The protein patterns of these strains as determined by polyacrylamide slab gel electrophoresis were remarkably uniform and were similar to the pattern of strain ATCC 33285 (Fig. 3). The most striking difference between these strains and the type strain was that seven of the eight produced indole. Other phenotypic reactions of these strains that differed from those of strain ATCC 33285 were as follows: one strain did not ferment glucose; one strain (a different one) did not ferment lactose or galactose; two strains did not ferment arabinose, dextrin, or inulin; three strains did not ferment melibiose, raffinose, or salicin; four strains did not ferment xylose; five strains did not ferment pectin; three strains did

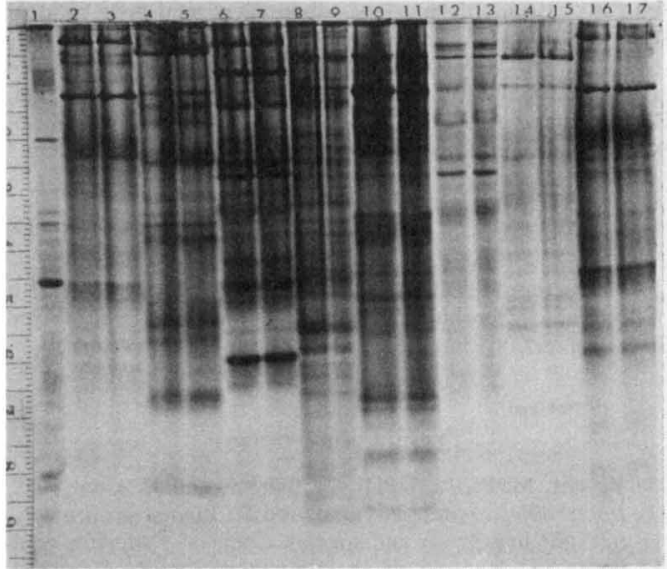

FIG. 4. Electrophoretic pattern of soluble cellular proteins of duplicate cultures of biochemically similar Bacteroides species. Lane 1, Streptococcus faecalis reference strain U4-20; lanes 2 and 3, ATCC 33285 (type strain of Bacteroides zoogleoformans); lanes 4 and 5 , ATCC 33269 (type strain of $B$, oralis); lanes 6 and 7, ATCC 8492 (type strain of $B$. uniformis); lanes 8 and 9, ATCC 19189 (type strain of $B$. ruminicola subsp. ruminicola); lanes 10 and 11 , ATCC 19188 (type strain of $B$. ruminicola subsp. brevis); lanes 12 and 13 , ATCC 33573 (type strain of $B$. oris); lanes 14 and 15, ATCC 33574 (type strain of $B$. buccae); lanes 16 and 17, ATCC 33285 (type strain of Bacteroides zoogleoformans).

not produce $\mathrm{H}_{2} \mathrm{~S}$; one strain was resistant only to penicillin $\mathbf{G}$; two strains were resistant only to tetracycline; one strain was resistant only to chloramphenicol; and none of the eight strains liquefied gelatin even weakly. Some of the variation was probably caused by the difficulty in delivering a uniform inoculum even after the culture, in carbohydrate-free medium, was vigorously agitated on a Vortex mixer.

The biochemical reactions of strains of $\mathrm{Bac}$ teroides zoogleoformans are quite similar to those of Bacteroides oralis, Bacteroides ruminicola (1), Bacteroides uniformis, and the recently described species Bacteroides oris and Bacteroides buccae (5), but the electrophoretic patterns of the soluble cellular proteins of the type strains of these species are distinctive (Fig. 4). The mucoid viscous mass formed in broth cultures by strains of Bacteroides zoogleoformans is not found in cultures of the other species.

\section{ACKNOWLEDGMENTS}

We thank Pauletta C. Atkins, Luba Fabrycky, and Donald E. Hash for excellent technical assistance and John L. John- 
son for determining the deoxyribonucleic acid base ratio of strain ATCC 33285.

This work was supported in part by Public Health Service grants DE05130-01 (from the National Institute of Dental Research) and AI15244-01A1 (from the National Institute of Allergy and Infectious Diseases).

\section{REPRINT REQUESTS}

Address reprint requests to: Elizabeth P. Cato, Department of Anaerobic Microbiology, Virginia Polytechnic Institute and State University, Blacksburg, VA 24061.

\section{LITERATURE CITED}

1. Bryant, M. P., N. Small, C. Bouma, and H. Chu. 1958. Bacteroides ruminicola $\mathrm{n}$. $\mathrm{sp}$. and Succinimonas amyloly. tica, the new genus and species. Species of succinic acidproducing bacteria of the bovine rumen. J. Bacteriol. 76:15-23.

2. Hauduroy, P., G. Ehringer, G. Guillot, J. Magrou, A. R. Prévot, D. Rosset, and A. Urbain. 1953. Dictionnaire des bactéries pathogènes, 2nd ed. Masson and Co., Paris.

3. Holdeman, L. V., E. P. Cato, J. A. Burmeister, and W. E. C. Moore. 1980. Descriptions of Eubacterium timidum sp. nov., Eubacterium brachy sp. nov., and Eubacterium nodatum sp. nov. isolated from human periodontitis. Int. J. Syst. Bacteriol. 30:163-169.

4. Holdeman, L. V., E. P. Cato, and W. E. C. Moore (ed.).
1977. Anaerobe laboratory manual, 4th ed. Virginia Polytechnic Institute and State University, Blacksburg.

5. Holdeman, L. V., W. E. C. Moore, P. J. Churn, and J. L. Johnson. 1982. Bacteroides oris and Bacteroides buccae, new species from human periodontitis and other human infections. Int. J. Syst. Bacteriol. 32:125-131.

6. Marmur, J., and P. Doty. 1963. Determination of the base composition of deoxyribonucleic acid from its thermal denaturation temperature. J. Mol. Biol. 5:109-118.

7. Moore, W. E. C., D. E. Hash, L. V. Holdeman, and E. P. Cato. 1980. Polyacrylamide slab gel electrophoresis of soluble proteins for studies of bacterial floras. Appl. Environ. Microbiol. 39:900-907.

8. Moore, W. E. C., and L. V. Holdeman. 1973. New names and combinations in the genera Bacteroides Castellani and Chalmers, Fusobacterium Knorr, Eubacterium Prévot, Propionibacterium Orla-Jensen, and Lactobacillus Beijerinck. Int. J. Syst. Bacteriol. 23:69-74. (As corrected in Int. J. Syst. Bacteriol. 24:311, 1974.)

9. Prévot, A. R. 1938. Études de systématique bactérienne. Ann. Inst. Pasteur Paris 60:285-307.

10. Prévot, A. R., A. Turpin, and P. Kaiser. 1967. Les bactéries anaérobies, 272-273. Dunod, Paris.

11. Skerman, V. B. D., V. McGowan, and P. H. A. Sneath (ed.). 1980. Approved lists of bacterial names. Int. J. Syst. Bacteriol. 30:225-420.

12. Weinberg, M., R. Nativelle, and A. R. Prévot. 1937. Les microbes anaérobies, 724. Masson and Co., Paris.

13. Wilkins, T. D., and T. Thiel. 1973. A modified broth-disk method for testing the antibiotic susceptibility of anaerobic bacteria. Antimicrob. Agents Chemother. 3:350-356. 